\title{
Sir Lewis Namier: an Eastern European's Historical Outline
}

Mark Baker

\begin{abstract}
Sir Lewis Namier is well known for the method of historical research that he developed. His emphasis on intense primary source research, attention to political structures, and concentration on the motivation of individual historical actors have been incorporated, in varying degrees, into the methodology of most historians. Yet, an examination of his essays on Eastern Europe suggests differences and similarities between Namier's historical work on Eastern Europe and his work in other areas. An explanation of these differences suggests that the historian who atomized eighteenth-century British history also had the ability to synthesize those "atoms" into a broad historical outline. This important and often overlooked aspect of this most enigmatic of historians is brought out clearly in his work on Eastern Europe.
\end{abstract}

From the beginning, his life was a marginal and deeply ambiguous one. Born in 1888 , so frail that he was initially given up as dead, Ludwik Bernsztajn vel Niemirowski spent most of his youth on his family's estates in Eastern Galicia. ${ }^{1}$

With these two sentences Linda Colley began her description of the childhood of this "frail" infant, who was to become Sir Lewis Bernstein Namier, one of the most influential British historians of our time. Colley, in attempting not only "to recover Namier as a historian but also to discover and interpret him anew," described Namier's childhood experiences in only two and one half pages. . More importantly, she discussed almost none of Namier's works concerning the area of the world of his childhood, Eastern Europe. This paucity of attention can be easily understood because Colley's focus was primarily on Namier's work on eighteenth-century Britain. Almost all of those who have written about this extremely important historian have limited their discussions to this area of Namier's historical work, for his greatest impact has undeniably been on British history. As A.J.P. Taylor and Richard Pares claimed, "the political history of England has been permanently reshaped; and its study will continue to bear the stamp of Sir Lewis Namier's inspiration."3

But Namier did not write only about Britain. In fact, he was quite prolific on subjects closer to his origins. He published a number of important works on European diplomatic affairs and the Revolutions 
of 1848. He wrote about dictators like Napoleon III and Hitler and also about the origins of the latter's Third Reich. Namier also wrote a number of articles about Eastern Europe. Colley was well aware of Namier's origins and that his interest in that area of the world continued throughout his life, yet she neglected to examine his historical writings on Eastern Europe. Since Namier spent most of his youth in that part of the world, one might argue that much could be learnt about the man, and the historian, through an analysis of his work on that area.

Like Colley's work, this paper focuses primarily on Namier's historical writings and is not biographical. Namier's wife, Julia, has already provided us with an uncommonly insightful account of his personal life. Of course, as Namier would have no doubt insisted, in analyzing his work on Eastern Europe, it will be necessary to integrate the more important biographical details. But the gains from our investigation will not be so much insights into this historian's personal life, as into his ideas about Eastern Europe and about history and how it should be approached. Namier's writings in this area appear quite different from those of his primary focus. Closer examination reveals a mixture of similarities and differences. An explanation of these differences suggests that the historian who atomized eighteenth-century British history also had the ability to synthesize those many atoms into a broad historical outline. Therefore, this examination broadens our understanding of Namier's method and provides a useful counterpoint to Colley's.

Of course, Colley is not the only historian who has discussed Namier's life and work. The historiography on Lewis Namier, as a subject, is not extensive. Some historians have simply written personal reflections on Namier. Like Julia Namier's book, these accounts make no claims to objectivity, but they are useful in trying to understand Namier as a person and in pointing out the importance of his Eastern European origins. ${ }^{4}$ Those historians who have analyzed Namier's historical work have tended to focus on Namier's method. This method involved an obsession with hard facts, precise dating, and the collection of data. Namier was interested in the constituents of social cohesion, the structure of elite groups, and, particularly, the psychology of the individual. His method required intensive research and attention to historical details. Using a structural analysis, and emphasizing the importance of self interest in the motivation of the individual, Namier down-played the explanatory value of ideas in history. ${ }^{5}$ Interpretations and applications of Namier's method have varied with each historian. In 1964, this variance led John Brooke, who actively collaborated with Namier in the writing of his last great work, The History of Parliament: The House of Commons 1754-1790, to try to define Namier's method more clearly. ${ }^{6}$ For example, Brooke objected to A.J.P. Taylor's assertion 
that Namier's disbelief in the explanatory value of ideas had taken the mind out of history. Brooke contended that, "it would be more correct to say that he was among the first to take into history the post-Freudian conception of the mind." In 1975, Peter Gay and Gerald J. Cavanaugh also tried to define the Namier method, but in more critical terms. They noted that Namier's method led one to look at history through a microscope and that it focused too narrowly on political history, alone. ${ }^{8}$

A more intense criticism of Namier's method was published in 1957. Herbert Butterfield, in George III and the Historians, criticized the Namier school for its narrow and atomistic approach. Butterfield admitred that Namier's method was important because it brought real analysis to history and generated a great mass of detailed research, but he argued that this atomization did not necessarily lead to greater understanding. It could, in fact, obscure understanding if one did not take into account the wider realm of politics and ideas. "In other words, historical judgement may be incorrect if based on the analytical method which abstracts things and subdivides the life with which it deals." Butterfield argued that Namier reduced political motivation to selfinterest to the exclusion of all else. But Butterfield confined his discussion to Namier's work on eighteenth-century Britain.

In fact, although some attention has been paid to Namier and his work, the focus has not been on Eastern Europe. Like Colley, most historians consider Namier's work in British history to be of primary importance. They rarely analyze his work on Western Europe and do not mention his work on Eastern Europe. Yet Namier's experience and interest in that area remained important to him throughout his life. Namier grew up as a Polonized Jew in Eastern Galicia. His education there familiarized him with a number of different cultures and provided him with an inside look at that area of the world. He left Galicia for Britain in 1907 at the age of nineteen. Despite his mainly British postsecondary education, his interest in Eastern Europe continued. In 1915, shortly after taking a first class degree in Modern History at Balliol College, Oxford, he found employment with the Foreign Office. There, he was so respected as an authority on Eastern Europe that he was soon assigned to the prestigious Political Intelligence Department as an expert on that area. This department consisted of a number of top British academics who provided the British government with in-depth historical analysis of the nations and peoples involved in World War I. Namier's employment kept him well informed on the current happenings in Eastern Europe and gave him valuable experience in international affairs. Colley suggested that it also had a significant impact on Namier's historical writing: "In the long term, this direct exposure to political intrigue and diplomatic manoeuvre would enrich Namier's 
historical work, lending it a degree of authority and confidence denied to most 'don-bred dons'."10

Namier continued to correspond with friends and relations in the East and even travelled there when he could. His interest in Eastern Europe was further encouraged by his second wife Julia de Beausobre, a Russian emigre, who was, herself, a well respected Russian poet. ${ }^{11}$ Throughout his life, Namier continued to read quite extensively in Russian history and literature. For example, in a letter to Julia in March 1945 , he wrote, "My greatest pleasure during these last few days has been reading at night War and Peace in Russian." ${ }^{2}$ He was also fluent in a number of other Eastern European languages including German, Polish, and Ukrainian. Clearly, his knowledge and continued interest in Eastern Europe also supports the contention that much could be learned from examining how he viewed this area of the world as a historian.

Namier's view of Eastern European history can be found mainly in the book he published in 1947, Facing East. This book is a compilation of articles on Eastern Europe that Namier originally wrote for various other publications. It may be argued that, "in considering these scholarly exercises in journalism as a contribution to serious historical study we are in fact applying a different set of criteria to them to those which their author can have had in mind in writing them." ${ }^{13}$ D.C. Watt proposed this criticism in a discussion of Namier's essays on Western Europe, only to refute it. He justified a rigorous examination of the collected essays on the basis that Namier compiled these "scholarly exercises in journalism" into books. "But Sir Lewis has himself chosen to give them a more permanent status, and they must therefore be judged by sterner and more lasting standards." ${ }^{14}$ Although, this argument would seem also to justify our examination, it is based on the assumption that when a historian compiles articles into book form, this signifies his recognition of them as history.

This assumption, at least in Namier's work on Eastern Europe, is difficult to prove. Namier did not give a clear indication of his intention in compiling and publishing Facing East. The compilation has no overall preface or introduction to tie the essays together. All that is provided is a page of acknowledgments, and all that these five lines acknowledge is the original journals of publication and the date on which the compilation was completed, 10 January 1947. However, Namier did provide a short note at the beginning of one section of the book, the series of essays on Russia. In this brief passage, Namier mentioned that the original dates of publication of the first three essays on Russia were 10 March 1943 and 14 and 15 January 1944 . He then stated that he had reproduced them "unchanged". He continued, "I 
even eschew alterations which I otherwise should have made to avoid repeating certain points from the preceding essay [on Poland]." 15 It would appear that Namier was more interested in preserving the original form of the articles than removing inconsistencies. Namier went on to state that, "the form of these articles reflects the time of their publication; but the underlying contentions seem to me as valid as they were then." 16 This last statement indicates that Namier felt the articles on Russia were pertinent three years after their original publication. The fact that he deliberately did not update them suggests that he intended them to become, not merely comments on the history of Eastern Europe, but material for analysis by future historians. If Namier compiled this book to preserve articles that he believed reflected "the time of their publication," then their use as sources to help us understand that time and, more importantly, the historian who wrote those articles, is justified.

Yet Namier did make some revisions when he compiled Facing East. The changes made to the articles do not substantially refute Namier's comment that he reproduced them "unchanged." Namier was only referring, specifically, to the first three articles on Russia, and the changes to these articles were insignificant. Only the article, "Britain, Russia, and Europe," was altered in any way. In commenting on American isolationism, Namier left out of the revision a political comment on "certain American groups" that had been promoting the idea that repugnance of European affairs should include "an anti-British colouring." 17 In addition, in the same paragraph, Namier added a sentence to the revised article. He reinforced his criticism of Americans who denied the closeness of their country's ties to Europe with a comparison to Russia: "And as for the man of Kazan, he is far more remote from Europe than the man of Kansas." 18 These rather minor revisions did little more than reinforce the argument and cannot be seen as important; however, the revisions to other articles in this book seem more substantial.

In his review of Eugene Tarle's book, Napoleon's Invasion of Russia, 1812, Namier added a paragraph. The paragraph expanded on a preceding point that Emperor Alexander had planned to use the vast wasteland of Russia to stop Napoleon's invasion. Namier argued that the Emperor had considered this strategy long before Napoleon invaded. ${ }^{19}$ This amendment was substantial; however, the entire paragraph really only expanded on the original article's point, that as early as May 1812, Alexander was prepared to lose some battles and retreat from others in order to stop Napoleon eventually..$^{20}$ More importantly, on an essential point in the revision of the same article, a point that had been debated in subsequent editions of the Times Literary Supplement, 
Namier did not change a word.

Namier's review appeared on 9 January 1943. On 27 February 1943, J.E. Edmonds commented on it. He disputed Namier's point that, as part of the strategy of Admiral Kutuzov, Alexander's military leader, he had intended to let the French army escape. Edmonds recalled a letter that Alexander had written to another Admiral, named Chichagov. He contended that the letter instructed the Russian admirals "to destroy the French armies, but to let Napoleon escape and on no account to harm him." ${ }^{21}$ The debate did not end there. On 13 March 1943, Philip Grierson suggested to Edmonds that he must have been mistaken. He found that no evidence, including that provided by Edmonds, indicated that there was "the least hint of any desire on the Tsar's part to allow Napoleon to escape from Russia." ${ }^{22}$ Edmonds responded to Grierson a week later. He assured Grierson that he was.not mistaken and that their differences over the interpretation of the Tsar's letter to Chichagov were due to Grierson's poor translation. ${ }^{23}$ Namier did not become directly involved in the debate and made no changes at all to this important section of his article when he reproduced it in Facing East. This would seem to support the contention that Namier had reproduced these articles essentially unchanged.

Furthermore, it should be mentioned that both Grierson and Edmonds had missed Namier's point. Namier had not argued that Alexander had allowed Napoleon to escape, but that Kutuzov had: "Russia's interest was served by the French evacuating her territory, and he [Kutuzov] did not care about Europe. His closest collaborators believed that at Beresina Kutuzov allowed Napoleon to escape." 24 Namier had spent the entire paragraph on which Edmonds made his criticism, discussing Kutuzov's "own firm plan". It would appear, therefore, that the debate between Edmonds and Grierson was beside the point. Regardless of Alexander's position on the French retreat and on whether the beleaguered Russian army should attack, Kutuzov, the commander in the field, had decided against it. It is important, then, to note that Namier did not bother to point this out to either Grierson or Edmonds. On a controversial point in his review, he had chosen neither to expand further nor to clarify his point in the version of this article that appeared in Facing East.

In sum, the above examples suggest that Namier's revisions to his original articles were sometimes insignificant, and sometimes expansions on important points, but they did not alter the essential arguments from their initial presentation. Much more significant differences can be found by comparing Namier's historical work on Eastern Europe as a whole to his work on other areas.

If one were to judge Namier's estimation of Eastern Europe's role in 
history solely on the quantity of material he wrote on the subject, one would conclude that he thought little of it. The first important difference between Namier's writings on Eastern Europe and the rest of his historical work is this difference in quantity. Namier actually wrote only two books which dealt with Eastern Europe. The first of the two, Germany and Eastern Europe, was in essence a pamphlet on what Namier believed to be the causes of the First World War. Germany's influence in Eastern Europe was at the heart of the problem. "The origin of the war lies in Eastern Europe. By skilful management German diplomacy could have prevented British, perhaps even French intervention in the war . . . German statesmen failed to make the best of their opportunities and especially to take advantage of the British "schoolboy" view of foreign politics." 25 This theme of German culpability runs throughout Namier's work on Europe. In fact, for the most part this pamphlet deals with Germany, not Eastern Europe. It might be questioned whether it should be considered to be one of Namier's historical works, or, even whether it constituted Eastern European history.

Facing East was the one book that Namier did write specifically on Eastern Europe. Unfortunately, it was only 159 pages long and not all of those pages concerned Eastern Europe. Despite the title of the book, only eight of the essays discussed this area. The first article actually dealt with Napoleon III; the second and third, with German history; and the last three out of fourteen, with Jewish history. In addition to Facing East, Namier's book, Conflicts: Studies in Contemporary History, included two short reviews of books on the Ukraine and Carpatho-Russia. Compared to Namier's quite substantial output on British and European history, this contribution was relatively small. Of course, one cannot simply dismiss these works on this basis. In fact, an important question to ask would be why this Polonized Jew, who grew up in Eastern Europe, did not give greater attention to this area in his historical writings?

A second difference between Namier's Eastern European work and his other work lies in the vehicle he used. Apart from England in the Age of the American Revolution, all of Namier's historical works were presented in books that were collections of essays. Sometimes the articles were closely related, and at other times the relations were very loose. Facing East was very much in the latter category. Of greater significance, however, was the type of articles that this book contained. Five of the eight articles that concerned Eastern Europe were book reviews. Like the two pieces in Conflicts, these reviews consisted of "that peculiar English sort of book reviewing in which the writer doesn't really review a book but merely uses it as a point of departure for a 
disquisition of his own." ${ }^{26}$ This comment by Carlton J.H. Hayes referred to another of Namier's collections, Avenues of History. Although Hayes suggested that there might be something unsatisfactory about this type of historical vehicle, he did admit that "the disquisitions of Professor Namier are always interesting and usually both penetrating and provocative."27 The reviews in Facing East and in Conflicts are all of the type that Hayes so aptly described. Namier's prolific use of this vehicle in his work on Eastern Europe was a significant departure from his other historical work.

His choice of this vehicle suggests another difference. As reviews appearing in newspapers, these articles had no bibliographies and insufficient footnoting. It is difficult to determine the sources that Namier consulted. Of course, the book being reviewed would have been the main source, but these articles indicated a far wider range of sources than could be provided by an individual book. A clear example of this was Namier's article on Yugoslavia, in which he did not mention the book that he was reviewing, Rebecca West's Black Lamb and Grey Falcon, until almost a third of the way through the review. ${ }^{28}$ The first three articles on Russia that were not reviews also lacked footnotes. It would appear, then, that the method that Namier developed and that "permanently reshaped" the political history of England, was not always followed by its originator. As already mentioned, this method demanded intensive research and close attention to the details of historical events and actors. Clearly, this method necessitated extensive footnoting, the absence of which must be considered an indication that the method itself was not being used. Namier may have done considerable research into the topics discussed in the books he reviewed. Certainly, his Eastern European origins, position with the Political Intelligence Department, language fluency, and extensive reading would have given him a good background on that area's history. However, if no evidence is provided that he carried out the kind of research that he demanded of British historians, one can only conclude that the Namierite method was put aside when its creator wrote about Eastern Europe.

A fourth difference, also relating to Namier's method, was the lack of attention given to the individual historical actor. Namier's focus on the individual culminated in his massive undertaking, The History of Parliament: The House of Commons, 1754-1790. "He sought to grasp the meaning of the political mechanism by understanding the men who controlled and used it. The History of Parliament, on which he laboured to the end, was precisely such a prosopographical study." ${ }^{29}$ This focus was evident in only two of the ten chapters of Facing East. And these two chapters, "The First Mountebank Dictator" and "Leadership in Israel: Chaim Weizmann", did not really deal with Eastern Europe at all. 
Perhaps in Eastern Europe, Namier was examining nations as individuals in themselves. In an article in which Namier concisely explained the "Basic Factors in Nineteenth-Century European History", he stated, "I pass to the alignment of the European Great Powers and the interplay of their interests and policies. What were in 1815 the leading dramatis persone on the European stage?" 30 This allusion may have simply been included for dramatic effect, or it may indicate the kind of individual Namier preferred to concentrate on when discussing European history. To some degree, the articles in Facing Eastconsidered the interactions between individual nations. Two articles focused on specific Eastern European countries: Poland and Yugoslavia. Four of the articles on Russia dealt with its relations with the outside world; however, within these articles, Namier also dealt with specific groups, such as the separate nationalities of Yugoslavia and the Russian peasants. Moreover, considering Namier's focus on the individual historical actor, it is unlikely that this was his intention. If he considered it a necessity to study history through first understanding the minutiae by atomization, he could not at the same time have argued that one could generalize about an individual nation without attention to the many individuals that comprised it. And Namier provided no evidence that the individual had first been studied. Clearly, then, in several respects, Namier's methodology and approach to Eastern European history contrasted sharply with his other work, and particularly with his studies of eighteenth-century Britain.

In spite of these differences in approach, Namier's work on Eastern Europe still exhibiced themes found in his other work. These themes cannot be clearly divided into those that stemmed from personal biases and those that he came to promote through his many years of historical investigation. Most probably, they were as much the result of his biases as of his accumulated historical perceptions.

For example, Namier did not simply believe in the rule of the oligarchy because he held some mystic conception about the importance of the possession of land. His historical investigations led him to conclude that it was the dominant progressive form of political rule. This can be seen clearly in his Eastern European writings. Often, when Namier appeared to be lamenting the passing of the ruling oligarchies of Eastern Europe, it was because of his understanding of the achievements of oligarchic rule rather than a romantic vision of the past. In his rather critical review of Bernadotte E. Schmitt's collection of essays, entitled Poland Namier argued that many of the essays placed the blame for all Poland's woes on the three Partitioning Powers: Prussia, Russia, and Austria. According to Namier, the political terror of, and economic exploitation by, the three Partitioning Powers formed "the 
leit-motif of the Polish writers." 31 Yet, as Namier pointed out, for much of the successive periods of subjugation to these Powers, "Polish hands" controlled the governments of both Polish and Ukrainian Galician territories. Namier's real criticism, then, of the Poles' use of the Partitioning Powers as scapegoats was very much that this analysis left out of Polish history the reign of an important Polish oligarchic elite group. "Why thus wipe out a chapter of Polish history-in which the Poles learnt and achieved a great deal? The Cracow Conservatives (the so-called Stanczyki) were one of the most important political groups which Poland ever produced, her enlightened Tories." ${ }^{22}$ Namier railed against Polish historians who blamed the Partitioning Powers, but ignored the contribution of the Polish oligarchy.

Namier's article on "East-Central Europe" also conveyed the theme of the rule of oligarchy. Although his review of Hugh Seton-Watson's book, Eastern Europe Between the Wars, 1918-1941, was quite favourable, he did not agree with Seton-Watson's conclusion that democracy in Eastern Europe was possible because the people wanted more food, land, justice, and personal security, and despotism could not provide these things. ${ }^{33}$ Namier objected that this contradiction did not necessarily give them the capacity for democracy. In what was probably the most "Namierite" comment of the article, Namier provided his interpretation of what was necessary for the development of democracy. "All government is based on some form of oligarchy: and the moral and intellectual level of the men who compose it and the view they take of government and their responsibility towards the governed matter far more than their social origins." ${ }^{\text {4 }}$ The problems in this part of the world stemmed from the wars and revolutions of the past which had corroded, broken up, and destroyed the traditional administration. In conclusion, Namier regretted the passing of this necessary precondition for democracy: "The old ruling classes have practically disappeared on the European continent: they perished mostly because they were not equal to the task; but even so their countries are the poorer." ${ }^{35}$ Clearly, Namier's historical perception that the rule of the oligarchy has been essential throughout history was also conveyed in his work on Eastern Europe.

Another theme of Namier's work that comes out in his writings on Eastern Europe concerns his apparent veneration of Britain. As noted above, Europe's decline could be partly attributed to the fall of its ruling oligarchies. By contrast, Britain's oligarchy had been stable and quite successful. Colley suggested that Namier's European histories focused on why these states had failed to achieve Britain's social and political stability, territorial integrity, and freedom from militarism, while his British history "was very much a celebration of the country's governing 
elite and political pragmatism ..." 36 This theme was clearly brought out in Namier's more general work on Europe. He even wrote a book entitled, Europe in Decay, analyzing the causes of Europe's decline. Namier's historical perception of the success of Britain and the comparative failure of Europe was also brought out consistently in his work on Eastern Europe. Russia was not included in Namier's conception of European decay. In an article on the relations of Britain, America, and Russia with the European nations, Namier contrasted the success of Britain with the failure of Europe:

There is a tradition of spiritual unity in Europe, deriving from Rome. Bur whenever in the last three centuries a nation or dynasty tried to recreate this politically, by establishing its own predominance over Western Christendom, it met with the conscious and tenacious resistance of England; and in defeating these threats to her own freedom and independence, England has gained about half of White Man's Land outside of Europe for her language, culture, and tradition. ${ }^{37}$

As this quotation clearly points out, Namier viewed Europe as considerably less successful than his adopted country. This perception was given significant attention in his work on Eastern Europe.

If the rule of the oligarchy provided Namier with the reason for Britain's historical predominance and stability, the other two important themes found in his Eastern European work, nationalism and the German problem, suggested the causes of Europe's decay. Colley stated that nationalism and Germany were "for Namier the two dynamic forces in modern European history." ${ }^{38}$ An examination of Namier's Eastern European work supports this statement.

It cannot be denied that Namier's attitude to Germany at times bordered on hatred. This was not surprising, considering that he was a Jew, an ardent Zionist, and was writing these articles during, and immediately following, the Second World War and the Holocaust. The propositions that he pur forward in his pamphlet on Germany and Eastern Europe asserted that Germany was to blame for the First World War and was inevitably militaristic. For Namier, the events of the Second World War only served to prove those propositions. Namier's review of Schmitt's book argued that geography played a role in the development of German militarism. "The centrifugal configuration of Germany favoured expansion but impeded unity; there is no focal district or capital to bind together the three Germanies of the Rhine, the

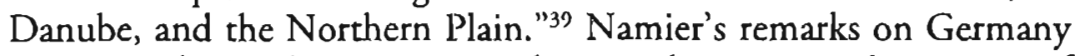
were not always this unemotional, or explanatory. In his review of 
Rebecca West's book on Yugoslavia, Namier took particular note of West's condemnation of the German invasion of that country. "In 1941-5 defeat and destruction were repeated, wrought once more by men as horrible 'as personages in a nightmare,' and so vile (as Rebecca West says of an individual German) nobody who is not one of them can believe how bad they are." 40 Infrequently, such examples of rather emotional condemnation can be found in Namier's work on Eastern Europe. However, it should be mentioned that Namier's assertions about the Germans, and their culpability in the devastations of the twentieth century, were not without some historical merit. This interpretation may be disputable today, but it was much more understandable and acceptable in an era of Nazi militarism. As Colley pointed out, Namier's "thesis that Germany must bear prime responsibility for the two world wars was accepted and adopted by a majority of diplomatic historians." ${ }^{41}$

Yet Namier did not blame all the devastation of the twentieth century on the Germans. Although the inevitability of German militarism was implicit in Namier's article on Russo-Polish relations, one comment suggests that the actions of all the Great Powers contributed substantially: "The friendship of Russia enabled Bismarck to erect the mighty edifice of the Second Reich; the estrangement between the Western Powers and Russia enabled Hitler and his Third Reich to attain predominance in Europe." ${ }^{2} 2$ The German cause was aided by the inability of these other Great Powers to consort together properly and thereby keep German militarism under control. Namier did assert that Germany's role in the international conflicts of our century was primary, but this more evenhanded account suggests that he was willing to spread some of the culpability to the other major powers.

More importantly for Namier, this culpability also had to be shared with the more extreme forms of nationalism that have raged through Europe in the last two centuries. Considering Namier's insistence on deflating the role of ideas in explaining the motivation of individuals, particularly in his historical interpretations of eighteenth-century British politics, this focus on nationalism at first seems misplaced. However, as Colley pointed out, Namier "never denied that ideas existed: he was in fact appalled at their power to disturb individuals and disrupt society. But he did not believe that historians should take expressed ideas at their face value." ${ }^{\prime 3}$ It was not that ideas had no role in history, but that the motivation of individuals was more complex and could not be explained by these ideas alone without regard to other factors, in particular, self-interest.

Understanding Namier's conception of nationalism is further complicated by his political advocacy of certain nationalistic claims. He was 
an ardent Zionist and also promoted Ukrainian and Polish independence during the revolutions that followed the First World War. Taras Hunczak suggested that Namier's position at the Political Intelligence Department allowed him to promote the Ukrainian cause effectively. He had established himself as "the most outstanding authority on the Galician and Polish questions" and had gained the respect and confidence of the Department. ${ }^{44}$ Namier's influence there led the members of the department to promote the Ukrainian cause in the immediate post-World War I period. "Together they [the members of the department] helped to shape the British foreign policy in Eastern Europe that provided the beleaguered Galician Ukrainians with sympathy and support from the most unexpected quarters." ${ }^{45}$ In fact, Hunczak went on to suggest that Namier's personal influence was primarily responsible for this aspect of British foreign policy.

In order to understand Namier's promotion of nationalistic causes, which apparently contradicts his condemnation of nationalism as a major contributor to the decay of Europe, we must describe more precisely how he defined different forms of nationalism. A comment from Namier's article on Poland suggested the distinction he considered useful. "There is beauty, grandeur, and parhos in Poland's history ... There is intense interest in the interplay of different conceptions of the 'political nation'; of nationality, territorial and linguistic, and in the part which Poland has played in international affairs, and foreign Powers in Polish history." 46 Namier also distinguished between these two types of nationalism, territorial and linguistic, in his article, "Nationality and Liberty." On the one hand, he promoted territorial nationalism. This form fostered a communal consciousness that coincided with the territory of the State. National awareness was identified with a particular territory and not a particular language or culture. This policy was the most effective way to promote individual liberty, because all members of the society within a particular territory would be equal, regardless of local cultural and linguistic variations. ${ }^{47}$ On the other hand, linguistic nationality actually proved detrimental to liberty because it promoted a single language and culture. Namier claimed that this latter form of nationalism was the only truly revolutionary idea that had originated in the Revolutions of 1848 , and its promotion had been devastating: "The demand that the State should be co-extensive with linguistic nationality was an internationally revolutionary postulate which seeing that nations are seldom linguistically segregated, proved destructive of constitutional growth and of international peace." 48 Namier promoted the self-determination of the Ukrainians after the First World War, because he believed it to have been a tolerant form of territorial nationalism. But when he witnessed first-hand the misuse of 
the term "self-determination" by extreme nationalist groups, his attitude changed. Namier concluded that "vitiated 'self-determination' put a strain on 'democracy' among the beneficiaries as well as among the aggrieved; and 'agrarian reform' itself became an instrument of warring nationalisms." 49 In his discussion of East-Central Europe, Namier implied that these "nationalisms" destroyed any hope of real agrarian reform, because they used it as a tool to remove any unwanted landed ruling nationality.

Perhaps because of his earlier advocacy, Namier was most vehement in condemning the linguistic and cultural exclusivity of the "integral nationalism" that some Ukrainians began to promote prior to and during the Second World War. In his review of Peter Winch's book Republic for a Day, he described the new Ukrainian nationalists: "The lower middle classes, intellectually half-baked and intoxicated, have entered active politics; and, infected with the virus of nationalism and 'leadership', they make life a misery for those who merely wish for a normal existence." 50 Obviously, Namier did not think much of the more recent young nationalists. He did admit, however, that the movement had negative and positive aspects. In fact, he praised Winch's book, because its even-handed approach brought out "the attractive side of the Ukrainian movement, but also its childish bombastic conceit, its imitation of Nazism, and its violence." 51 As this quotation points out, Namier believed that the mould from which a plethora of Eastern European integral nationalistic movements were formed was Nazi Germany. "And though no other European nation has gone the same length as the Germans, the German concept of nationality, largely through the influence which German political formations and deformities had on Central and Eastern Europe, has become dominant on the Continent." 52 Therefore, according to Namier, it was the interaction between these two forces, nationalism and Germany, that had led to the decay of Europe, and evidence of these historical perceptions can be found in Namier's work on Eastern Europe as much as any where else.

The themes of admiration for the oligarchy and the British political system, and the pernicious impact of German militarism and linguistic nationalism were clearly carried into Namier's Eastern European work. Although these themes indicate significant similarities across Namier's various fields of study, they do not explain why Namier's methodology and approach were not applied to his historical interpretations of Eastern Europe. Since no explanation was provided by Namier or by his wife's biography, one must be cautious in attempting to resolve this inconsistency.

The most obvious explanation of these differences was that Namier simply had no time. Namier's method and his intensive approach to 
research were extremely time-consuming. His work on massive projects, such as the three volumes on the House of Commons, left little time for other areas of study. The atomization of the House of Commons for the period 1754 to 1790 , involving an intensive historical examination of each individual member, consumed almost all of Namier's time in his later years. As well, Namier was not only a historian. G.S. Rousseau argued that Namier actually tried to live three lives at once: as a historian, a diplomat, and an ardent Zionist. Rousseau considered this role as a "triumvirate" to be the most determinant aspect of Namier's whole life, and as a result "he was continually finding himself in moments of crisis or revelatory awareness about his allegiances, rendering it impossible for him to forsake one for the other." 53 Obviously, these three occupations left little time for Namier to apply his intensive historical method in any other areas of interest than those of primary importance.

Moreover, it is clear that Namier's area of primary focus was British history. His fascination with the British political system suggested this focus. No matter how many different interests Namier had, his main interest was always eighteenth-century British Parliamentary history. John Brooke argued that "many misconceptions about Namier's work disappear when it is realized that he was primarily a historian of Parliament." 54 The time-consuming nature of the Namier method and his focus on the historical development of the British parliamentary system, left little time to apply that same method to other fields of interest.

The unavailability of primary sources on Eastern Europe provides a further explanation. There is no question that, throughout most of Namier's life in Britain, sources on Eastern Europe were difficult to obtain. The fall of the iron curtain locked away the most important archival material on that area of the world. Even Western European sources were limited at the time that Namier wrote the articles for Facing East. In 1950, three years after that book's release, Namier was still waiting for the most crucial sources to become available to him before revising one of his books on interwar Europe. "I do not mean to attempt rewriting Diplomatic Prelude cill the most important collections of documents for the pre-war years are published ..."55 Namier was also concerned about the reliability of evidence coming from Europe and from Eastern Europe, in particular. In his article on the Curzon line, he implied that nationalistic motives had led to considerable confusion over census figures. "It is impossible to check with any degree of accuracy misleading entries in the census itself." 56 His wife noted Namier's acute awareness of the unreliability of Russian primary sources. "When 'torn out pages' are many, their absence forms a 'great 
void and burden', which L [Namier] detected in Russian history ... The Torn Out Pages had long been intended as the title of a novel to be written by him one day." 57 These quotations clearly indicate that Namier, possessing considerable personal knowledge about Eastern European history, was also fully aware of the scarcity and unreliability of sources on that topic. Obviously, the British sources were far more readily available and he considered them to be much more reliable. Thus, the two necessities for Namier's intensive approach to serious historical research -- time and sources -- were not available for the historical study of Eastern Europe.

Apparently because of these problems, Namier abridged his approach. Since he had neither the time nor the resources to apply his intensive methodology, he looked to other people to do the research for him. So, for example, he used Rebecca West's already accumulated facts on Yugoslavia to write his historical work on that country. Namier noted the great deal of knowledge that one could extract from West's book. "Besides vision, art, and humour, there is in Rebecca West's book a great fund of knowledge -- old, accumulated knowledge, or new, acquired in working on this book: for in it there is several years' labour extended over wide and varied regions." ${ }^{8}$ Namier's positive appraisal of this book stemmed from the interpretations that West's "fund of knowledge" allowed him to make. He warned reviewers that West had failed to summarize her own book, and he apparently intended his review to complete the task, to sum up West's mountain of accumulated facts.

In reviewing W.E.D. Allen's book, The Ukraine: A History, Namier admonished the author for a similar failure "to summarize the relevant material." 59 This failure once more provided Namier with an opportunity to do his own summarizing, without having personally assembled the relevant material. Namier praised Winch's book, Republic for a Day, because the author had refrained "from discoursing too much." In fact, the books that Namier preferred to review often contained a wealth of facts that their accumulators had not 'properly' summarized. Namier's historical writings on Eastern Europe consisted primarily of interesting disquisitions based primarily on the research of others. These summaries presented the broad outline of an Eastern European history that, for various reasons, Namier never got around to writing.

John Brooke, who worked with Namier for nine years on The House of Commons, divided Namier's work into two types. On the one hand, he wrote long books based on detailed research studying very short periods of time, and on the other hand, he wrote a lot of brief essays on vast subjects. "What matters in history," Namier wrote, "is the great outline and the significant detail: what must be avoided is the deadly 
mass of irrelevant narrative." ${ }^{11}$ Namier's work on Eastern Europe was well within his description of "the great outline." Therefore, this work can also be placed within the Namierite method. Namier never had the time, resources, or inclination to approach Eastern European history in the way that he approached British history. He could not provide the very significant detail. Instead, he provided the equally important broad outline. Even the briefest perusal of his work on Eastern Europe, provides ample proof of his ability to do the latter just as well as the former.

Our discussion of Sir Lewis Namier's work on Eastern Europe has led to certain conclusions about this influential historian. Even though Namier's limited treatment of Eastern European history indicated the relatively low importance he placed on the events that occurred there, it is clear that examining this limited body of work broadens our understanding of his method. Although Namier's methodology and approach were not evident in his discussions of these countries, his historical perceptions were. Nationalism, German militarism, the veneration of the British political system, and the significance of the rule of the oligarchy were themes that Namier continued in his work on Eastern Europe. Moreover, Namier has often been accused of atomizing history to the detriment of overall historical understanding. However, in writing about Eastern Europe, he was able to synthesize other writers' atomized facts and bring out the larger picture, "the great outline". 


\section{NOTES}

${ }^{1}$ Linda Colley, Lewis Namier (New York, 1989), 7

2 Ibid., 4. The two and a half pages describing Namier's childhood are pp. 7-9.

${ }^{3}$ Richard Pares and A.J.P. Taylor, eds., Essays Presented to Sir Lewis Namier (London, 1956), v

"Julia Namier, Lewis Namier: A Biography (London,1971); Arnold Toynbee, "Lewis Namier, Historian," Encounter 16(January 1961), 39-43; Isaiah Berlin, "L.B. Namier: A Personal Impression," Journal of Historical Studies 1(Winter 1967-8), 117-136; G.S. Rousseau, "Namier on Namier," Studies in Burke and His Time 8(Fall 1971), 2016-2041; A.J.P. Taylor, A Personal History (London, 1983), 114. All of these mention Namier's continued interest in Eastern Europe throughout his life.

${ }^{5}$ Much of this description comes from Colley, Namier, 43-4.

"John Brooke, "Namier and Namierism," History and Theory: Studies in the Philosophy of History 3(1964), 331-47

${ }^{7}$ Ibid., 339

${ }^{8}$ Peter Gay and Gerald J. Cavanaugh, eds., Historians at Work, vol. vi,(London, 1975), 276

${ }^{9}$ Herbert Butterfield, George III and the Historians (London, 1957), 299

${ }^{10}$ Colley, Namier, 11

"Julia Namier, Lewis Namier, 264-5. Julia's merit as a poet was quite well known. Boris Pasternak once wrote to her stating that if she left Russia, "a Russian poet of considerable promise would be committing suicide" (Ibid., 265).

12 Ibid., 260. As well, Namier often spoke to Julia in Russian and would occasionally drift into it in casual conversation.

13 D.C. Watt, "Sir Lewis Namier and Contemporary European History," Cambridge Journal 7(1954), 580-581

${ }^{14}$ Ibid., 581

${ }^{15}$ L.B. Namier, Facing East (London, 1947), 96

${ }^{16}$ Ibid., 96

17 L.B. Namier, "Britain, Russia, and Europe: Conditions of Continental Security," The Times, 10 March 1943, 5

${ }^{18}$ Namier, Facing East, 99

19 Ibid., 115

${ }^{20}$ L.B. Namier, "Russia's Way with Invaders," Times Literary Supplement, 9 January 1943, 18

${ }^{21}$ J.E. Edmonds, "Napoleon's Invasion of Russia," Times Literary Supplement, 27 February 1943, 103

${ }^{22}$ Philip Grierson, "Napoleon's Invasion of Russia," Times Literary Supplement, 13 March 1943, 127

${ }^{23}$ Edmonds, "Napoleon's Invasion of Russia," 139

${ }^{24}$ Namier, Facing East, 120 (my italics added)

${ }^{25}$ Lewis B. Namier, Germany and Eastern Europe (London, 1915), ix 
${ }^{26}$ Carlton J.H. Hayes, review of Avenues of History, by L.B. Namier, American Historical Review 58 (1952-3), 575

${ }^{27}$ Ibid., 575

${ }^{28}$ Namier, Facing East, 66-71

${ }^{29}$ Gay and Cavanaugh, Historians at Work, 275

${ }^{30}$ Sir Lewis Namier, "Basic Factors in Nineteenth-Century European History," in L. B. Namier, Vanished Supremacies: Essays on European History, 1812-1918(New York, 1958), 169

${ }^{31}$ Namier, Facing East, 93-4

32 Ibid., 95

${ }^{33}$ Ibid., 64

${ }^{34}$ Ibid., 64

${ }^{35}$ Ibid., 65

${ }^{36}$ Colley, Namier, 15

${ }^{37}$ Namier, Facing East, 99-100

${ }^{38}$ Colley, Namier, 34

${ }^{39}$ Namier, Facing East, 83

${ }^{40} \mathrm{Ibid}$., 82

${ }^{41}$ Colley, Namier, 93

${ }^{42}$ Namier, Facing East, 108

${ }^{43}$ Colley, Namier, 26-27

${ }_{44}^{4}$ Taras Hunczak, "Sir Lewis Namier and the Struggle for Eastern Galicia, 19181920," Harvard Ukrainian Studies 1(June 1977), 199

${ }^{45}$ Ibid., 199

${ }^{46}$ Namier, Facing East, 90 (my italics added for emphasis)

${ }^{47}$ L. B. Namier, "Nationality and Liberty," in Vanished Supremacies, 31 ${ }^{48}$ Ibid.

${ }^{49}$ Namier, Facing East, 53

${ }^{50}$ L.B. Namier, Conflicts: Studies in Contemporary History (London, 1942), 181 (my emphasis added)

st Ibid., 183

52 Namier, "Nationality and Liberry," 35

53 Rousseau, "Namier on Namier," 2024-2025

${ }^{54}$ Brooke, "Namier and Namierism," 334

${ }^{55}$ L.B. Namier, Europe in Decay: A Study in Disintegration, 1936-1940 (London,1950), $\mathbf{v}$

${ }^{56}$ Namier, Facing East, 112

57 Julia Namier, Lewis Namier, 264. "L" was a term of endearment by which Julia and Namier's close friends called him. (Incidencally, the theme of "Torn Out Pages" is a major theme in Russian history.)

58 Namier, Facing East, 75

59 Namier, Conflicts, 175. This article originally appeared in the Times Literary Supplement on 11 January 1941. 